\title{
Impact of MOOC on increasing student interest in the learning process in the context of blended learning
}

\section{Impacto do MOOC no aumento do interesse do aluno no processo de aprendizagem no contexto do blended learning}

\section{Impacto de MOOC en el aumento del interés de los estudiantes en el proceso de aprendizaje en el contexto del aprendizaje combinado}

\author{
Tatiana Aleksandrovna Ivashkina $^{1}$ iD, Valentina Nikolaevna Sidorenko $^{2}$ iD, \\ Elena Ivanovna Sukhova² iD
}

\footnotetext{
${ }^{1}$ Moscow Aviation Institute (National Research University), Moscow, Russia.

${ }^{2}$ Moscow City Teacher Training University (MGPU), Moscow, Russia.
}

\section{Corresponding author:}

Tatiana Aleksandrovna Ivashkina

Email: ivashkinatat@yandex.ru

How to cite: Ivashkina, T. A., Sidorenko, V. N., \& Sukhova, E. I. (2022). Impact of MOOC on increasing student interest in the learning process in the context of blended learning. Revista Tempos e Espaços em Educação, 15(34), e17297. http://dx.doi.org/10.20952/revtee.v14i33.17297

\begin{abstract}
The present study aims to substantiate the necessity of using MOOCs in the learning process in higher education institutions, as well as to develop and describe the particular components of a method for using MOOCs in organizing blended learning. The article substantiates the relevance of using MOOCs in the conditions of blended learning and presents various approaches to the definition of MOOC and blended learning. The results of comparative analysis of world MOOC platforms, a model for the integration of a MOOC into the structure of an academic discipline, and the results of an empirical study of engaging students in the use of MOOCs in the conditions of blended learning are presented. MOOCs can be used at different stages of studying academic disciplines in higher education institutions: in laboratory classes or individual assignments, in the process of students' independent work, their preparation for mid-term and final tests. The study concludes that MOOCs are advisable for use in the educational process and it is important to engage students to take them.
\end{abstract}

Keywords: Massive open online course. Distance learning. Blended learning. MOOC platform. Online courses. 


\section{RESUMO}

O presente estudo visa fundamentar a necessidade da utilização de MOOCs no processo de aprendizagem em instituições de ensino superior, bem como desenvolver e descrever as componentes particulares de um método de utilização de MOOCs na organização do blended learning. $\mathrm{O}$ artigo fundamenta a relevância do uso de MOOCs nas condições de blended learning e apresenta várias abordagens para a definição de MOOC e blended learning. São apresentados os resultados da análise comparativa de plataformas mundiais de MOOCs, um modelo para a integração de um MOOC na estrutura de uma disciplina acadêmica e os resultados de um estudo empírico de engajamento de alunos no uso de MOOCs nas condições de blended learning. Os MOOCs podem ser usados em diferentes etapas do estudo de disciplinas acadêmicas em instituições de ensino superior: em aulas de laboratório ou trabalhos individuais, no processo de trabalho independente dos alunos, na preparação para testes intermediários e finais. O estudo conclui que os MOOCs são aconselháveis para uso no processo educacional e é importante engajar os alunos para realizá-los.

Palavras-chave: Curso online aberto massivo. Ensino à distância. Aprendizado híbrido. plataforma MOOC. Cursos online.

\section{RESUMEN}

El presente estudio tiene como objetivo fundamentar la necesidad de utilizar los $\mathrm{MOOC}$ en el proceso de aprendizaje en instituciones de educación superior, así como desarrollar y describir los componentes particulares de un método para utilizar los MOOC en la organización del aprendizaje combinado. El artículo fundamenta la relevancia del uso de MOOC en las condiciones del aprendizaje combinado y presenta varios enfoques para la definición de MOOC y aprendizaje combinado. Se presentan los resultados del análisis comparativo de las plataformas mundiales de MOOC, un modelo para la integración de un MOOC en la estructura de una disciplina académica y los resultados de un estudio empírico de involucrar a los estudiantes en el uso de MOOC en condiciones de aprendizaje combinado. Los MOOC se pueden utilizar en diferentes etapas del estudio de disciplinas académicas en instituciones de educación superior: en clases de laboratorio o tareas individuales, en el proceso de trabajo independiente de los estudiantes, su preparación para exámenes parciales y finales. El estudio concluye que los MOOC son recomendables para su uso en el proceso educativo y es importante involucrar a los estudiantes para que los tomen.

Palabras clave: Curso en línea abierto masivo. La educación a distancia. Aprendizaje mixto. Plataforma MOOC. Cursos online.

\section{INTRODUCTION}

The modern information society is characterized by the intensive and massive introduction of new technologies in all spheres of life. Among the modern trends in education, it is possible to highlight the use of modern pedagogical technologies and the personalization of learning, distance learning technologies, cloud technologies, mobile learning, and massive open online courses (MOOCs) (Dzyuba et al., 2021; Afanasiev et al., 2021). These instruments not only affect the content and quality of education but to some extent determine the selection of the methods, means, and forms of organizing learning.

A special place in the professional activities of any specialist is occupied by the skills of independently acquiring new knowledge, skills, and abilities, self-organization, and continuous professional development (Yefremtseva et al., 2019). This gives rise to an urgent need for training competitive specialists able to orient in the rapidly changing information society and capable of selflearning.

One of the strategies to resolve the issue of training specialists who can quickly master new knowledge and learn throughout their lives is the use of MOOCs in higher education and further 
professional activity (Kovalevskaia et al., 2021). In our opinion, a pedagogically justified introduction of MOOCs into the educational process will help familiarize students with the possibilities of using MOOCs, expand their understanding of the accessibility of studying professional disciplines using the courses of famous world universities, and promote the development of their self-education and self-development skills (Wagner et al., 2021).

\section{LITERATURE REVIEW}

Given that massive open online (distance) courses and blended learning are two rather interrelated concepts, we will briefly analyze some studies on the issue. Some researchers (Jordan, 2015; Baker, Passmore, 2016; Emanuel, 2013) describe MOOCs as a type of distance learning that can involve a large number of participants (up to 50,000) while offering open access to all materials via the Internet (Jordan, 2015); as one of the forms of distance learning (Baker, Passmore, 2016); and as educational courses on some disciplines that are studied using information technologies and the Internet (Emanuel, 2013).

Thus, MOOCs refer to educational courses published on the Internet with free access that are characterized by two key features: open access and mass nature. Open access implies that the course is free and open to the public, and mass nature suggests that many participants from all over the world take part in it.

O. Pilli and W. Admiraal (2016) explore the structure of different types of MOOCs and the specifics of their realization. The offers state that MOOCs offer a wide variety of disciplines in many areas: engineering, humanities, medicine, biology, social sciences, mathematics, business, information technology, etc. The priorities of the listeners of online courses remain unchanged as long as they have existed: the most popular are courses on the basics of computer sciences, statistics, business, and management. Specialized educational online platforms for virtual learning in creative disciplines (music, art) also start to appear.

Several studies (Emanuel, 2013; Czerniewicz et al., 2017) closely examine the pedagogical and organizational features of the organization of world MOOC platforms. A. Lane, S. Caird, and M. Weller (2014) conduct a historical analysis of the emergence and development of MOOCs in the world. M.H. Mohamed and M. Hammond (2018 address the theoretical and practical aspects of using MOOCs in higher education.

Studies by C.O. Rodriguez (2012) and G. Fischer (2014) mostly provide comparative characteristics of the use of open online courses, statistical data on the distribution of courses by different branches of science, and the number of registered listeners and analyze the ratio of students who completed the course, those who took it partially, and those who simply enrolled in the course without any active engagement.

D. Andone and V. Mihaescu (2018) describe the experience of introducing MOOCs into the system of classic academic disciplines at universities and analyze the opportunities for using online learning tools and their influence on the development of professional competencies.

Special attention should be paid to the study by M.J. Israel (2015), which analyzes the possible paths of using MOOCs in blended learning and presents conclusions on the effectiveness of learning using MOOCs and its effect on students and teachers.

Researchers in the field of blended learning offer different approaches to the definition of the concept (Table 1). 
Table 1. Approaches to defining the concept "blended learning"

\begin{tabular}{|l|l|}
\hline Source & Approaches to defining the concept "blended learning" \\
\hline Wivell, Day & $\begin{array}{l}\text { combination of formal means of learning (work in classrooms, studying theoretical material) and } \\
\text { innovative (electronic) forms of learning (discussion by email, Internet-conferences, joint work in a } \\
\text { telecommunication learning project of creating blog-quests, doing practical exercises, and posting } \\
\text { their results on the portfolio website, etc.) }\end{array}$ \\
\hline $\begin{array}{l}\text { Garrison, } \\
\text { Kanuka } \\
(2004) .\end{array}$ & $\begin{array}{l}\text { a purposeful learning process carried out by educational institutions of various types within the } \\
\text { framework of formal education, part of which is implemented remotely using ICT and technical } \\
\text { means of learning, which allow to store and deliver educational material, implement control } \\
\text { activities, and organize interaction between the subjects of the learning process (consultations, } \\
\text { discussions), and which involves students' self-control of the time, place, routes, and pace of } \\
\text { learning }\end{array}$ \\
\hline $\begin{array}{l}\text { Jeffrey et al. } \\
(2014)\end{array}$ & $\begin{array}{l}\text { various combinations of the forms and methods of organizing formal, non-formal, and informal } \\
\text { learning, as well as self-study, carried out to achieve predetermined learning objectives while } \\
\text { maintaining a mechanism to control the time, place, routes, and pace of learning }\end{array}$ \\
\hline
\end{tabular}

Blended learning allows combining the use of digital learning resources and a variety of online services for the implementation of educational activities. In particular, researchers point to the following tools that provide for such a combination: learning management systems (Moodle, aTutor, ILIAS, etc.) (Stockwell et al., 2015), online training courses (Coursera, edX, Udacity, Khan Academy, etc.) (Auster, 2016), tools for creating educational resources and content (tools for designing of tests, forms, questionnaires, interactive tasks) (Graham, 2013), communication and feedback instruments, collaboration instruments (mainly based on cloud technologies) (McGee, Reis, 2012), tools for creating communities (social networks, forums, blogs) (Donnelly, 2020), and learning activity planning tools (electronic journals, calendars and the like) (Tynan et al., 2015).

Scientific studies described above partially address the issues of introducing MOOCs into the system of higher education and examine the problem of blended learning. However, they do not clarify how MOOCs need to be included in the education system and how exactly they should be integrated into the structure of the study of academic disciplines of specialist training.

The present study hypothesizes that open online courses can be used at different stages of studying academic disciplines in higher education institutions: in laboratory classes or individual assignments, in the process of students' independent work, their preparation for mid-term and final tests.

Objectives of the study are:

- to analyze theoretical achievements in regards to the degree of development of the problem of using MOOCs in blended learning;

- to substantiate the need to use MOOCs in the educational process of higher education institutions;

- to develop and describe the particular components of a method for using massive open online courses in organizing blended learning.

The article is composed of an introduction, literature review, methods, results, discussion, and conclusion.

\section{METHODS}

\section{Model of the study}

To achieve the goal set for the present work, an analysis of scientific literature on the problem under study is conducted; the scientific publications selected for analysis concern the issues of the method for the study and integration of MOOCs into the educational process.

The conducted experimental study involves engaging students to use MOOCs in the conditions of blended learning. The experimental study on the use of MOOCs in specialist training 
includes 10 teachers who provide professional training and 40 students. An introductory survey of the students is administered before the start of the academic disciplines to establish:

- the level of students' knowledge of the possible ways of obtaining new knowledge, selfeducation, and obtaining distance education;

- students' knowledge of the opportunities to use MOOCs to obtain education and their experience in using MOOCs.

After the introductory survey, the students are informed of the content of the corresponding course, their structure, and the option of substituting one of its modules with a corresponding online course, the possible ways for students to use MOOCs to organize their independent work and prepare for mid-term and final control of academic achievement are outlined.

At the end of the semester, the students are offered to complete the final survey.

\section{Research methods}

The study employs theoretical methods (literature analysis, comparison of researchers' views on the use of MOOCs in teaching students, generalization and systematization of theoretical material on the studied problem) and empirical methods of research (student survey, conversations with students and teachers, analysis of the results of the experimental study).

\section{Mathematical processing of the study results}

Mathematical and statistical methods of processing the results of the study include processing the results of the survey.

\section{RESULTS}

The results of the literature analysis allow us to state that the most popular global MOOC platforms providing access to online courses are Coursera, edX, FutureLearn, Khan Academy, and Udemy. Table 2 shows the results of our comparative analysis of the most popular global MOOC platforms.

Table 2. Comparative characteristic of world MOOC platforms

\begin{tabular}{|c|c|c|c|c|c|}
\hline Characteristic & Coursera & edX & FutureLearn & Khan Academy & Udemy \\
\hline Registration & Mandatory & Mandatory & Mandatory & Optional & Mandatory \\
\hline Language support & $\begin{array}{l}\text { English } \quad+ \\
\text { subtitles }\end{array}$ & $\begin{array}{l}\text { Primarily } \\
\text { English }\end{array}$ & $\begin{array}{l}\text { Primarily } \\
\text { English }\end{array}$ & $\begin{array}{l}\text { English } \\
\text { subtitles }\end{array}$ & $\begin{array}{l}\text { Primarily } \\
\text { English }\end{array}$ \\
\hline Method of access & $\begin{array}{l}\text { Online, iOS app, } \\
\text { Android app }\end{array}$ & $\begin{array}{l}\text { Online, iOS app, } \\
\text { Android app }\end{array}$ & $\begin{array}{l}\text { Online via the } \\
\text { browser }\end{array}$ & $\begin{array}{l}\text { Online, iOS app, } \\
\text { Android app }\end{array}$ & $\begin{array}{l}\text { Online, iOS app, } \\
\text { Android app }\end{array}$ \\
\hline $\begin{array}{l}\text { Average course } \\
\text { length }\end{array}$ & 6-10 weeks & 4-12 weeks & 4 weeks & $\begin{array}{l}\text { Online courses } \\
\text { and lectures in } \\
\text { the form of } \\
\text { YouTube videos }\end{array}$ & $\begin{array}{l}2-6 \text { hours of } \\
\text { lectures }\end{array}$ \\
\hline Certificate option & Free certificate & $\begin{array}{l}\text { from } 49 \$ \text { for } \\
\text { the certificate }\end{array}$ & $\begin{array}{l}49 \$ \text { for the } \\
\text { certificate }\end{array}$ & no & $\begin{array}{l}\text { Only in fee- } \\
\text { based courses }\end{array}$ \\
\hline $\begin{array}{l}\text { Total number of } \\
\text { courses }\end{array}$ & $>5,000$ & $\sim 3,200$ & $\sim 1,950$ & $\begin{array}{l}\text { } 70,000 \\
\text { educational } \\
\text { videos, } \\
\text { assignments, } \\
\text { and tests }\end{array}$ & 130,000 \\
\hline
\end{tabular}

As demonstrated by the results of comparative analysis, most of the world MOOC platforms have their courses in English (many have subtitles in other languages), do not offer the opportunity to get a free certificate (with the exception of several courses on Coursera), and the length of the courses offered ranges between several weeks to several months. 
Relying on the results of the theoretical study, we have developed a model for the integration of Coursera MOOCs into the structure of an academic discipline (Figure 1).

\begin{tabular}{|c|c|c|c|c|}
\hline \multicolumn{5}{|c|}{ Classic academic discipline } \\
\hline Lectures & $\begin{array}{l}\text { Laboratory } \\
\text { classes }\end{array}$ & Independent work & Individual assignments & Control \\
\hline $\begin{array}{l}\text { Giving classic } \\
\text { lectures without } \\
\text { the use of } \\
\text { MOOCs }\end{array}$ & $\begin{array}{l}\text { The students } \\
\text { completing a short } \\
\text { MOOC instead of a } \\
\text { part of laboratory } \\
\text { classes }\end{array}$ & $\begin{array}{l}\text { The use of MOOCs for } \\
\text { performing some types } \\
\text { of independent work, } \\
\text { obtaining deeper } \\
\text { knowledge in the } \\
\text { academic disciplines }\end{array}$ & $\begin{array}{l}\text { Maximum individualization } \\
\text { of assignments by } \\
\text { performing real practical } \\
\text { tasks, taking into account } \\
\text { the needs of each student } \\
\text { with the opportunity to use } \\
\text { MOOCs }\end{array}$ & $\begin{array}{l}\text { The opportunity } \\
\text { to prepare for } \\
\text { mid-term tests } \\
\text { by completing } \\
\text { test assignments } \\
\text { in MOOCs }\end{array}$ \\
\hline
\end{tabular}

Figure 1. Model for the integration of MOOCs into the structure of an academic discipline

Conversations with teachers reveal that they believe MOOCs to be a promising means of activating students' learning activity and a means of organizing distance learning, although the majority of the teachers (70\%) have no experience of using MOOCs in the educational process. Analysis of the results of the introductory survey concludes that most students $(77.5 \%)$ are not informed of the ways of self-education and obtaining distance education. At the same time, some students have heard about platforms containing MOOCs (22.5\%) but have never registered there or taken a course. Only $17.5 \%$ of the students have completed MOOCs in different academic disciplines or for self-study.

Analysis of the results of the final survey shows that after the completion of experimental learning with the use of MOOCs as part of the selected disciplines, a part of students (40\%) got interested and started to study other disciplines through MOOCs and $72.5 \%$ of the students report that they intend to use MOOCs to study other academic disciplines or for self-education and advancing their knowledge in the future.

Since LMS Moodle has long been used as a means of organizing remote access to educational materials, it is interesting to know the respondents' opinions on the effectiveness and feasibility of its use in the organization of distance learning. Most of the students express the opinion that the publication of materials in LMS Moodle is convenient, provides quick access to lecture materials, assignments for laboratory work, and means of diagnostics of academic performance. However, the students argue that LMS Moodle should not be the only instrument supporting distance learning, and, accordingly, during the organization of distance or blended learning, it is worth considering the use of other means of access to training materials, chats, video conferencing facilities, MOOCs, and the like.

The survey results prove that for the majority of the students $(82.5 \%)$, MOOCs present a novel way of obtaining education, studying new disciplines, or advancing the knowledge they already have, yet are interesting and promising in the organization of independent work or distance learning.

Thus, the conducted pedagogical experiment proves the use of MOOCs to be feasible.

\section{DISCUSSION}

A significant impetus for the intensification of the search for ways to introduce blended (and in some cases purely distant) learning technologies and their active use in Russia was the quarantine and restrictive measures aimed at combating the global pandemic. Undoubtedly, the constant increase in the popularity of MOOCs is primarily due to the world processes of globalization and informatization and the deepening trends of accessibility and mass education [10]. On the other 
hand, the coronavirus pandemic was a small catalyst for the acceleration of the development of MOOCs as a form of education.

Researchers argue (Mohamed, Hammond, 2018) that the use of MOOCs in specialist training will allow students to discover the ways of using open online courses in the learning process and future professional activities, contribute to the development of their self-learning and selfeducation skills, open up new ways of mastering the studied academic disciplines, and, finally, become a form of obtaining higher education.

The results of the study suggest that the only thing that can partially limit the active use of MOOCs in the structure of classic disciplines is the problem of students' insufficient knowledge of foreign languages, particularly English. However, this issue can be resolved by using online courses on Russian MOOC platforms or through the search for and use of online courses by prominent world MOOC providers with subtitles in a language a student does speak.

Even though MOOCs are a new phenomenon in the modern education environment, especially in the Russian education system, we advise their partial introduction in the academic disciplines at higher education institutions. This makes it necessary to establish the ways for the integration of MOOCs into the structure of classic academic disciplines.

According to the curriculum and operational programs of disciplines, their study involves the use of the following types of student activities: lectures, laboratory classes, and independent work of students. Lectures and laboratory classes address the fundamental theoretical and practical issues of the studied disciplines. It is in the laboratory classes that the development of students' professional and specialized competencies takes place.

In our view, lectures should not use MOOCs but instead should be conducted in the form of a discussion of an educational problem with the analysis of the solutions to specific problems. However, due to a large number of available MOOCs and the shift of emphasis on the quality of practical training of future specialists, it is worth increasing the number of hours for laboratory classes at the expense of lecture hours.

To diversify students' activities in laboratory classes, popularize MOOCs, create favorable conditions for the intensification of students' learning activity, and foster the skills of organizing independent work, we propose that students replace laboratory work in one of the course modules with a relevant short MOOC if they wish. The MOOCs that could be used as such courses are the ones that correspond to the titles and semantic content of the modules and do not exceed 3-4 academic weeks in their duration (Pilli, Admiraal, 2016).

At the first introductory lesson, in the process of exploring the structure of an academic discipline, students are given a short presentation on the possibilities of using MOOCs and are offered to choose and complete one of the suggested MOOCs as an alternative to studying and assessment on one of the course modules. If the entirety (or a part of) the online course is completed, the student is given the appropriate number of points for a particular content module.

A significant part of the time during the study of academic disciplines is allocated for students' independent learning and cognitive activities, which involves preparing for lessons, completing the assignments given at lectures and in laboratory classes, performing individual assignments, and so on. We consider it expedient to use MOOCs as a form of students' independent work to consolidate knowledge on the studied topics or study the issues of the academic discipline that are not included in the content of lectures or laboratory classes.

Another important aspect of using MOOCs is the individualization of studying an academic discipline (Mohamed, Hammond, 2018). This implies students choosing and studying the open online courses that deepen and consolidate their knowledge, abilities, and skills in the exact issues that they consider the most interesting, promising, and needed in their future professional activities. 


\section{CONCLUSION}

The conducted study demonstrates the importance of engaging students to take MOOCs, since, to have modern, up-to-date knowledge, one needs to be constantly improving their level of knowledge, perfecting their abilities and skills. The encouragement of students to take MOOCs will contribute, first of all, to the development of their self-education skills, as well as broaden their outlook on the ways of obtaining knowledge in the modern information society and allow them to use MOOCs in future professional activities to improve and deepen their professional competencies, for continuous self-improvement.

The study supports the proposed hypothesis that open online courses can be used at different stages of studying academic disciplines in higher education institutions: in laboratory classes or individual assignments, in the process of students' independent work, their preparation for mid-term and final tests.

The conducted experiment on the inclusion of MOOCs in the process of future specialist training proves the feasibility of the use of MOOCs in the educational process, as the survey results show a great number of students becoming interested in taking MOOCs, and in the process of training, increased attention of students was focused specifically on the MOOCs.

Despite all the advantages of the use of MOOCs in the educational process, it has to be borne in mind that the degree of their integration into the structure of academic disciplines needs to be controlled and pedagogically justified, as excessive load with MOOCs may shift students' attention away from the classic academic discipline to online courses and compromise their interest in laboratory classes provided in the curriculum.

The issues that remain unresolved as of yet concern the technical, psychological, and pedagogical aspects of integrating MOOCs into the structure of classic academic disciplines in higher education institutions, which can become a prospect for further research.

Authors' Contributions: Ivashkina, T. A.: conception and design, acquisition of data, analysis and interpretation of data, drafting the article, critical review of important intellectual content. Sidorenko, V. N.: conception and design, acquisition of data, analysis and interpretation of data, drafting the article, critical review of important intellectual content. Sukhova, E. I.: conception and design, acquisition of data, analysis and interpretation of data, drafting the article, critical review of important intellectual content. All authors have read and approved the final version of the manuscript".

Ethics Approval: Not applicable.

Acknowledgments: Not applicable.

\section{REFERENCES}

Dzyuba, E.M., Zakharova, V.T., Latukhina, A.L., \& Sheveleva, T.N. (2021). Open education courses as a relevant environment for improving professional competencies of teachers. Revista Tempos e Espaços em Educação, 14(33), e16164. https://doi.org/10.20952/revtee.v14i33.16164

Afanasiev, I.V., Vysotskaya, N.V., Alferov, V.N., \& Grigorieva, N.A. (2021). The use of cloud resources and services in distance learning of students in the context of restrictions caused by the pandemic. Revista Tempos e Espaços em Educação, 14(33), e16103. https://doi.org/10.20952/revtee.v14i33.16103

Kovalevskaia, N., Gilyazeva, E.N., Lobazova, O.F., Duborkina, I.A., \& Sokolova, A.P. (2021). Impact of digital services of hybrid cloud-based learning environment on efficiency of education. Revista Tempos e Espaços em Educação, 14(33), e15297. https://doi.org/10.20952/revtee.v14i33.15297

25 Wagner, M.N., Kupriyanova, M., Ovezova, U., \& Ilina, A. (2021). Distance Learning Courses: New Opportunities for the Development of University Education. Propósitos y Representaciones, 9(3), 1275.

http://dx.doi.org/10.20511/pyr2021.v9nSPE3.1275

26 Yefremtseva, T.N., Batyrshina, A.R., Sagilyan, S.G., Sunaeva, S.G., \& Petrova, E.S. (2019). Independent Work as An Important Form of Formation of SelfEducational Competence of Students of Humanitarian Specialties. Amazonia Investiga, 8(20), 674-682. 
And one, D., \& Mihaescu, V. (2018). Blending MOOCs into Higher Education Courses-A Case Study. Learning With MOOCS (LWMOOCS), 2018, 134 - 136. https://doi.org/10.1109/LWMOOCS.2018.8534606

Auster, C.J. (2016). Blended learning as a potentially winning combination of face-to-face and online learning: An exploratory study. Teaching Sociology, 44, 39-48.

Baker, R.M., \& Passmore, D.L. (2016). Value and Pricing of MOOCs. Education sciences, 6(12), 14. https://doi.org/10.3390/educsci6020014

Czerniewicz, L., Deacon, A., Glover, M., \& Walji, S. (2017). MOOC-Making and open educational practices. Journal of Computing in Higher Education, 29, 81-97.

Donnelly, R. (2020). Harmonizing technology with interaction in blended problem-based learning. Computers \& Education, 54(2), 350-359.

Emanuel, E.J. (2013). Online education: MOOCs taken by educated few. Nature, 503(7476), 342.

https://doi.org/10.1038/503342a

Fischer, G. (2014). Beyond hype and underestimation: Identifying research challenges for the future of MOOCs. Distance Education, 35, 149-158.

Garrison, D.R., \& Kanuka, H. (2004). Blended learning: Uncovering its transformative potential in higher education. The Internet and Higher Education, 7, 95-105.

Graham, C.R. (2013). Emerging practice and research in blended learning, in: M.G. Moore (Ed.), Handbook of distance education. New York: Routledge.

Israel, M.J. (2015). Effectiveness of Integrating MOOCs in Traditional Classrooms for Undergraduate Students. International Review of Research in Open and Distributed Learning, 16(5), 102-118.

Jeffrey, L.M., Milne, J., Suddaby, G., \& Higgins, A. (2014). Blended learning: How teachers balance the blend of online and classroom components. Journal of Information Technology Education: Research, 13, 121-140.

Jordan, K. (2015). Massive open online course completion rates revisited: assessment, length and attrition. International Review of Research in Open and Distributed Learning, 76(3), 341-358.

Lane, A., Caird, S., \& Weller, M. (2014). The potential social, economic and environmental benefits of MOOCs: operational and historical comparisons with a massive 'closed online' course. Open Praxis International Journal, 6(2), 115-123.

McGee, P., \& Reis, A. (2012). Blended Course Design: A Synthesis of Best Practices. Journal of Asynchronous Learning Networks, 16(4), 7-22.

Mohamed, M.H., \& Hammond, M. (2018). MOOCs: a differentiation by pedagogy, content and assessment. International Journal of Information and Learning Technology, 35(1), 2-11. https://doi.org/10.1108/IJILT-07-2017-0062

Pilli, O., \& Admiraal, W. (2016). A taxonomy for Massive Open Online Courses. Contemporary Educational Technology, 7(3), 223-240.

Rodriguez, C.O. (2012). MOOCs and the Al-Stanford like courses: Two successful and distinct course formats for massive open online courses. European Journal of Open, Distance and E-Learning, 15, 13.

Stockwell, B.R., Stockwell, M.S., Cennamo, M., \& Jiang, E. (2015). Blended Learning Improves Science Education. Cell, 162(5), 933-936.

Tynan, B., Ryan, Y., Lamont-Mills, A. (2015). Examining workload models in online and blended teaching. British Journal of Educational Technology, 46(1), 5-15.

Wivell, J., Day, S. (2015). Blended learning and teaching: Synergy in action. Advances in Social Work and Welfare Education, 17(2), 86-99.

Received: 31 October 2021 | Accepted: 12 January 2021 | Published: 23 February 2022 